\title{
COMMENTARY
}

\section{Antagonism of $\mathrm{P}^{2} \mathrm{X}_{3}$-containing channels: commentary on Spelta et al.}

\author{
${ }^{*, 1}$ Michael F. Jarvis \& ${ }^{1}$ Edward C. Burgard
}

${ }^{1}$ Global Pharmaceutical Research and Development, Abbott Laboratories, 100 Abbott Park Road, Abbott Park, Illinois, IL 60064, U.S.A.

British Journal of Pharmacology (2002) 135, 1343 - 1344

Keywords: $\mathrm{P} 2 \mathrm{X}_{3}$ receptors; ligand association; competitive antagonism; TNP-ATP

The ATP-activated $\mathrm{P}_{2} \mathrm{X}_{3}$-containing receptors (homomeric $\mathrm{P} 2 \mathrm{X}_{3}$ and heteromeric $\mathrm{P} 2 \mathrm{X}_{2 / 3}$ ) have been implicated in the processing of nociceptive information from evidence that these receptors are highly localized on small diameter primary sensory afferent neurons (nociceptors), that their expression is altered in pain states, and that pharmacological blockade reduces nociception in animal models (see references in Spelta et al., 2002; Jarvis \& Kowaluk, 2001). The lack of truly potent and receptor-selective antagonists has hampered the pharmacological evaluation of $\mathrm{P}_{2} \mathrm{X}_{3}$ containing receptors. Early efforts to develop structure activity relationships (SAR) for $\mathrm{P} 2 \mathrm{X}$ receptor antagonists have focused on micromolar affinity nonselective compounds like suramin and pyridoxal-phosphate-6-azophenyl2',4'-disulphonic acid (PPADS) (Kim et al., 2001). As the present data by Spelta et al. (2002) clearly demonstrate, these two antagonists, as well as the nucleotide containing P2X receptor antagonist, trinitrophenyl-ATP (TNP-ATP), block $\mathrm{P} 2 \mathrm{X}_{3}$-containing receptors with very different kinetic properties and affinities.

But what determines the affinity of an antagonist? In the simplest sense, the Law of Mass Action states that affinity is defined by the dissociation constant $\left(K_{D}\right)$, or the ratio of dissociation/association rate constants. A common misconception among many biologists is that antagonist association rates are often relatively similar, and that the major determinant of affinity is the dissociation rate of the antagonist. After all, if an antagonist stays on the receptor longer, should it not display a higher affinity for that receptor? Studies with specific antagonists for a number of ligand-gated ion channels have suggested either that the dissociation rate is a primary determinant (Jones et al., 2001), or that a combination of association and dissociation rates (Benveniste \& Mayer, 1991; Wenningmann \& Dilger, 2001) governs antagonist affinity.

In the present study by Spelta et al. (2002) fast drug application techniques were used to measure real-time antagonist kinetics at $\mathrm{P} 2 \mathrm{X}$ receptors. By comparing the association and dissociation rates of three antagonists that display different affinities for $\mathrm{P}_{2} \mathrm{X}_{2 / 3}$ receptors, they have concluded that the antagonist association rate is a critical

*Author for correspondence: E-mail: michael.jarvis@abbott.com component of $\mathrm{P} 2 \mathrm{X}$ receptor antagonist affinity. In this study, TNP-ATP shows $>100$ fold higher affinity for the $\mathrm{P} 2 \mathrm{X}_{2 / 3}$ receptor than does suramin. The authors offer evidence that although the TNP-ATP dissociation rate is slightly slower, it is the 50 fold faster association rate that determines the increased affinity of TNP-ATP for the receptor. Likewise, although PPADS is shown to have an extremely slow dissociation rate, it exhibits only moderate affinity due to a correspondingly slow association rate. From these data, it is clear that antagonist association rates must be considered when addressing questions of relative antagonist affinity.

What are the practical implications of association rate differences between antagonists? One obvious consideration should be careful control of antagonist pre-incubation times in in vitro experiments. For a slowly associating antagonist, a pre-application of several minutes may be required to achieve steady-state binding interactions, as previously shown for NF279, a suramin analogue $\mathrm{P} 2 \mathrm{X}_{1}$ receptor antagonist (Rettinger et al., 2000). The work of Spelta et al. (2002) also illustrates the necessity for caution in the interpretation of agonist/antagonist interactions at the $\mathrm{P} 2 \mathrm{X}_{2 / 3}$ receptor. Using a bicistronic expression system, these authors obtained an approximate 50:50 ratio of rat $\mathrm{P} 2 \mathrm{X}_{2 / 3}$ to $\mathrm{P} 2 \mathrm{X}_{2}$ receptor expression that complicated any Schild analysis of receptor antagonism since the $\mathrm{P}_{2} \mathrm{X}_{3}$ receptor-selective agonist $\alpha, \beta$ meATP activates homomeric $\mathrm{P}_{2} \mathrm{X}_{2}$ receptors at high $\geqslant 100 \mu \mathrm{M}$ concentrations. Thus, for the most potent antagonist, TNP-ATP, these investigators note that $\mathrm{P} 2 \mathrm{X}_{2 / 3}$ receptor block was consistent with competitive antagonism, yet a Schild analysis for $\mathrm{P} 2 \mathrm{X}_{2 / 3}$ receptor block was not feasible. While not conclusively demonstrated, this interpretation is in agreement with our earlier work that characterized the apparent competitiveness of TNP-ATP to potently block human $\mathrm{P}_{2} \mathrm{X}_{2 / 3}$ receptors (Burgard et al., 2000). The competitive nature of TNP-ATP block of human $\mathrm{P} 2 \mathrm{X}_{2 / 3}$ receptors has been recently supported using a nondesensitizing chimeric human $\mathrm{P} 2 \mathrm{X}_{2} / \mathrm{P} 2 \mathrm{X}_{3}$ receptor that showed $\mathrm{P} 2 \mathrm{X}_{3}$-like pharmacology, but $\mathrm{P} 2 \mathrm{X}_{2}$-like desensitization (Uchic et al., 2001). Spelta et al. (2002) have also demonstrated kinetic differences between the traditional lower affinity $\mathrm{P} 2 \mathrm{X}$ receptor antagonists, suramin and PPADS. However, like TNP-ATP, the question of competitive versus non-competitive antagonism by these compounds has been debated, due to both low potency and nonspecific 
block of P2X receptor subtypes (Kim et al., 2001; Jacobson \& Knutsen, 2001). Novel high affinity and selective P2X receptor antagonists are clearly needed in this field, and their kinetic profiles will require careful characterization. Although structurally diverse $\mathrm{P} 2 \mathrm{X}$ receptor antagonists with enhanced

\section{References}

BENVENISTE, M. \& MAYER, M.L. (1991). Kinetic analysis of antagonist action at $\mathrm{N}$-methyl-D-aspartic acid receptors. Two binding sites each for glutamate and glycine. Biophys. J., 59, $560-573$.

BURGARD, E.C., NIFORATOS, W., VAN BIESEN, T., LYNCH, K.J., KAGE, K.L., TOUMA, E., KOWALUK, E.A. \& JARVIS, M.F. (2000). Competitive antagonism of recombinant $\mathrm{P} 2 \mathrm{X}(2 / 3)$ receptors by 2', 3'-O-(2,4,6-trinitrophenyl) adenosine 5'-triphosphate (TNPATP). Mol. Pharmacol., 58, $1502-1510$.

JACOBSON, K.A. \& KNUTSEN, L.J.S. (2001). P1 and P2 purine and pyrimidine receptor ligands. In Purinergic and Pyrimidinergic Signalling I: Molecular, nervous and urogenitary system function. Eds. Abbrachio, M.P., Williams, M. pp. 129-175. SpringerVerlag: Berlin.

JARVIS, M.F. \& KOWALUK, E.A. (2001). Pharmacological characterization of $\mathrm{P}_{2} \mathrm{X}_{3}$ homomeric and heteromeric channels in nociceptive signaling and behavior. Drug Dev. Res., 52, 220-231.

JONES, M.V., JONAS, P., SAHARA, Y. \& WESTBROOK, G.L. (2001). Microscopic kinetics and energetics distinguish GABA(a) receptor agonists from antagonists. Biophys. J., 81, 2660-2670. pharmacological selectivity have been slow to emerge and the evolution of $\mathrm{P} 2 \mathrm{X}$ receptor SAR is currently a more empirical than rational exercise, Spelta et al. (2002) have made a significant contribution to our understanding of the kinetics of the currently available $\mathrm{P} 2 \mathrm{X}_{3}$ receptor antagonists.

KIM, Y.-C., BROWN, S.G., HARDEN, T.K., BOYER, J.L., DUBYAK, G., KING, B.F., BURNSTOCK, G. \& JACOBSON, K.A. (2001). Structure-activity relationships of pyridoxal phosphate derivatives as potent and selective antagonists of $\mathrm{P} 2 \mathrm{X}_{1}$ receptors. $J$. Med. Chem., 44, 340-349.

RETTINGER, J., SCHMALZING, G., DAMER, S., MULlER, G., NICKEL, P. \& LAMBRECHT, G. (2000). The suramin analogue NF279 is a novel and potent antagonist selective for the P2X receptor. Neuropharmacology, 39, 2044-2053.

SPELTA, V., JIANG, L.-H., SURPRENANT, A. \& NORTH, R.A. (2002). Kinetics of antagonist actions at rat $\mathrm{P}_{2} \mathrm{X}_{2 / 3}$ heteromeric receptors. Br. J. Pharmacol., 135, 1524-1530.

UCHIC, M.E., BURGARD, E.C., NIFORATOS, W., JARVIS, M.F., FALTYNEK, C. \& LYNCH, K.J. (2001). Pharmacological and electrophysiological properties of a chimeric human P2X2/P2X3 receptor. Soc. for Neurosci. Abstr., 27, 158.9.

WENNINGMANN, I. \& DILGER, J.P. (2001). The kinetics of inhibition of nicotinic acetylcholine receptors by $(+)$-tubocurarine and pancuronium. Mol. Pharmacol., 60, 790-796. 